\title{
6 June 1944 - D-Day
}

Dr Irvine Eidelman is a psychiatrist in private practice. His special interests are anxiety and mood disorders, liaison psychiatry and visiting the Kalahari.

In his book Overlord Max Hastings said of D-Day, 6 June 1944: 'It has certainly made me all the more grateful that my generation has never been called upon to endure anything of the scale and ferocity that encompassed the men who fought in Normandy.'

The 60th anniversary of this remarkable and awesome landing on the coast of Normandy was celebrated on 6 June 2004. In a moving multinational ceremony at Arromanches we were reminded of the valour, courage and gallantry of the young men sent to invade and liberate France and ultimately Europe. My appreciation of the elements of this battle and its enormity of scale became all the more vivid when I had the honour to hear, first hand, the accounts of two veteran soldiers who were part of the Normandy Landings. A guided tour of Normandy under the supervision of a military historian jumbles one's senses of awe, shock and admiration.

Just before midnight on 5 June 1944, six Horsa gliders each towed by a Halifax bomber, a minute apart, were towed across the English Channel. In each glider were soldiers of the 6th Airborne Division under the command of Major John Howard. Their task ... to capture intact the bridges over the Caen Canal and Orne River and to hold the positions until relieved. As they approached the coast of Normandy the gliders cast off and in what has been described as the greatest feat of flying in the war, glider number 1 came to a grinding halt in darkness some 70 metres from the target, Pegasus Bridge. Glider number 2, one minute behind, also landed with pinpoint accuracy, while glider number 3 shot past glider 2 on landing, hit a hump and broke in two, its wooden fuselage shattered. It was now just after midnight.

The attack was a total surprise, and the first allied soldiers to set foot on the soil of Normandy stormed out of their gliders and achieved their objective with only one battle casualty.

Having intact bridges was crucial to the incoming sea invaders on Sword Beach, as the bridges would allow the

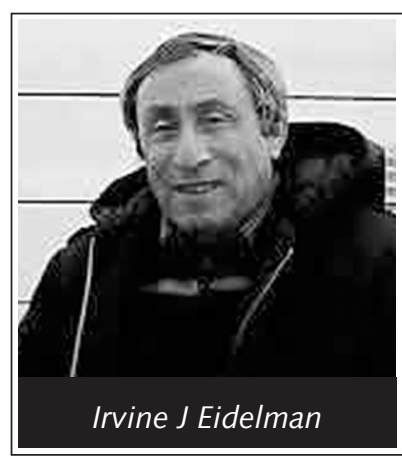

landing forces a path into the hinterland of Normandy and on to the strategic city of Caen.

From about 6.30 a.m. on D-Day, the allied landings on Utah, Omaha, Gold, Juno and Sword beaches began. Hearing the first-hand narrative of a soldier who disembarked at Gold Beach gave me a quite different perspective of the horrors of war. The reality of the landings, so vividly portrayed in Spielberg's 'Saving Private Ryan', was far more horrific than our wildest imaginings. The casualty rate was appalling, especially at Omaha. Today the peaceful Normandy countryside is the last resting place of the thousands of

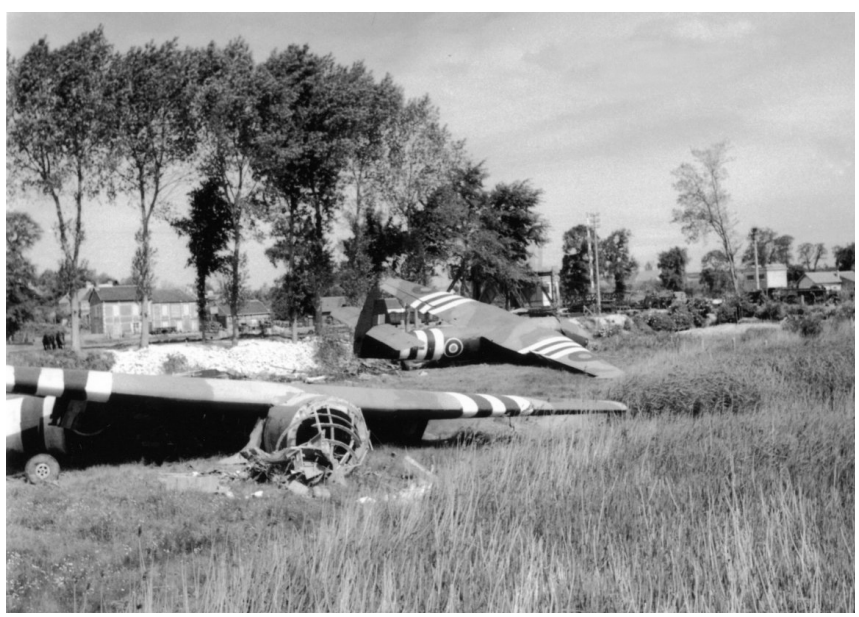

Pegasus bridge - gliders 1 and 3. 


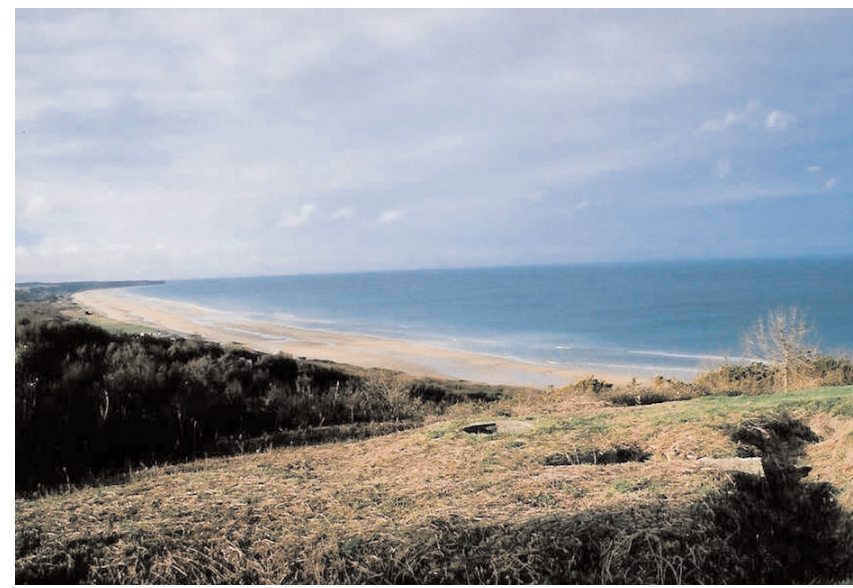

Gold Beach, Normandy.

soldiers who paid the ultimate price.

In a strange quirk of history the soldier who disembarked on Gold Beach eventually went over Pegasus Bridge, which had been captured by the soldier of the 6th Airborne, whose story I also heard. They only met 60 years later, here in South Africa.

Both soldiers sustained significant combat injuries. What they witnessed and endured was horrific. That they survived ... a miracle. Both have experienced and continue to experience vivid emotional flashbacks, horrific dreams, and other post- traumatic symptoms. They have patchy recall for some events, but maintain other memories in exquisite detail. Had they developed full-blown post-traumatic stress disorder no one would have been surprised.

Yet, despite what they went through, both led fully functional lives and both have retired. What made these two soldiers so resilient and resourceful? Was it their young age, their training, their commitment to the cause they were fighting for? Perhaps we need to further research the factors that may protect us from developing post traumatic stress disorders.

And perhaps the overriding challenge to mankind is to promote those factors that preserve peace and reduce crime.

\section{Irvine J Eidelman}

PO BOx 341

Plumstead

Cape Town

\section{Bibliography}

1. Ambrose SE. D-Day June 6, 1944: The Climactic Battle of World War II. London: Pocket Books, 1994.

2. Hastings M. Overlord: D-Day and the Battle for Normandy 1944. London: Pan Books, 1999.

3. Ambrose SE. Pegasus Bridge: D-Day: The Daring British Airborne Raid. London: Pocket Books, 1985 